\title{
Assessment of Fruit Flies Infestation on Gauva in Terai Region of West Bengal
}

\author{
G. Roy, N. Laskar and S. Sarkar*
}

Dept.of Entomology, Uttar Banga Krishi Viswavidyalaya, Pundibari, Cooch Behar, West Bengal (736 165), India

\section{Corresponding Author}

S. Sarkar

e-mail: surajskrento@gmail.com

\section{Article History}

Article ID: IJEP0286

Received in $12^{\text {th }}$ February, 2019

Received in revised form $20^{\text {th }}$ February, 2019

Accepted in final form $23^{\text {rd }}$ February, 2019

\begin{abstract}
The experiment was performed from September, 2014 to April, 2015 in order to determine the intensity of infestation by fruit flies in guava orchard in the northern district of West Bengal, India. A survey was conducted in the major guava growing areas of the terai and hilly region of West Bengal especially in northern district. From each location altogether one hundred (100) fruits were collected randomly at three times from the orchard and then taken to the laboratory and examined critically for fruit fly infestation. During 2014, results revealed that highest fruit fly infestation (25.00\%) was reported from Posarir Hat and lowest (9.67\%) from Kharibari. However, in the next year, i.e. during 2015, maximum fruit fly infestation (28.33\%) was reported again from Posarir Hat and lowest (8.67\%) from Matigara.
\end{abstract}

Keywords: Fruit fly, guava, infestation

\section{Introduction}

India is the second largest producer of fruits in the world with an annual production of 43 million tonnes, from an area of 4 million hectares, and contributes to more than $9 \%$ of world's fruit production (Sikhamany and Murti, 2005).To date, with increasing globalization, it has become a challenge for our country not only to feed its own population but also to export fruits and vegetables to various developed countries so as to earn foreign currency. This requires strict quality control and restrictive quarantine measures. Among all the fruits in India, the total area under guava cultivation was approximately 219,700 ha with an estimated annual production of 257 million ton. It was one of the most common and major fruits of India and was considered as the fifth most important fruit in respect of its area and production after mango, citrus, banana and apple. Guava, the "poor man's fruit" or "apple of the tropics" was a popular fruit tree of the tropical and subtropical climates.

Guava fruit is seriously damaged by different environmental factors and pests which include diseases, birds, insects and mites. About 80 species of insects have been recorded on guava trees, affecting yield and quality of fruits. Of these, less than 20 species occupy the status of major potential and minor pests. Rests of them are casual feeders. Fruit flies, bark-eating caterpillars, fruit borer and coccids (scale insects and mealy bugs) are considered as major pest of guava, while aphids, white flies, thrips, stem borers and fruit borers etc., are the minor pests (NHM, 2012). Tephritid fruit flies are one of the most high profile insect pests of commercial fruit and vegetable growers, marketing exporters, government regulatory agencies, and the scientific community. Locally, producers face huge losses without some management scheme manage fruit fly populations. At the national and international level, plant protection agencies strictly regulate the movement of potentially infested products. Consumers throughout the world also demand high quality, blemish-free produce. Partly to satisfy these demands, the costs to local, state and national governments are quite high and increasing as world trade, and thus risk increases.

The infestation of fruit fly is a major limiting factor in production of guava. It is in the ranges $20-46 \%$ with losses 16 $40 \%$ (Hasseb, 2007) and 5-7\% (Verghese et al., 2002a). Guava fruit has high demand but severe fruit fly infestation during summer by Anastrephastriata Schiner and Bactrocera zonata Saunders badly reduces the marketable yield, which results in significant economic losses to growers. Fruit fly prefers guava as a host and larvae causes the main damage by feeding inside the fruit during their growth and development (Stonehouse et al., 2005). Rotting of infested fruit results in excessive fruit drop and also makes it inedible for the consumers.

In addition to that northern part of West Bengal substantially contributes in different kinds of fruits production. In both fruits and vegetable production fruit flies appears regularly as one of the major hindrances. Fruit fly infestation being the major obstacle in the production and marketing of guava, successful cultivation and export are highly dependent 
on sound management of fruit fly. Based on the serious damage caused by fruit flies, it is very crucial to determine theinfestation level in field as it is one aspect of fundamental importance in the management of fruit flies. Therefore, this study was aimed to determine the infestation levels of fruit flies on guava in different locations of terai and hilly agro ecological region of West Bengal.

\section{Materials and Methods}

This study was conducted in a commercial guava orchard located in Cooch Behar, Jalpaiguri, Alipurduar and Darjeeling districts of West Bengal $\left(26.3357^{\circ} \mathrm{N}, 89.4459^{\circ} \mathrm{E}, 26.6835^{\circ}\right.$ $\mathrm{N}, 88.7689^{\circ} \mathrm{E}, 26.4919^{\circ} \mathrm{N}, 89.5271^{\circ} \mathrm{E}, 27.0360^{\circ} \mathrm{N}, 88.2627^{\circ}$ $E)$. Intensity of fruit fly infestation on guava was determined through survey on farmers field. The fruits were collected from different location of Cooch Behar, Alipurduar, Jalpaiguri and plains of Darjeeling district. From each locations altogether one hundred (100) fruits were collected randomly at three times i.e. early, mid and late stage of the crop during 2014 and 2015.The orchard was planted with four-year old guava with trees distributed in $6 \times 7 \mathrm{~m}$ spacing and conducted under conventional system during the experiment.These fruits were kept in laboratory for ripening in rearing cages under observation. The ripen fruits were cut and critically examined for the presence of fruit fly maggots under magnifying lens. The fruits with maggots of fruit fly were treated as infested fruits and without maggots were treated as healthy fruits. The observations on numbers of healthy and infested fruits were recorded and then infestation (\%) due to fruit fly was determined. Data obtained were analyzed by standard statistical package andpresented in both tabular as well as graphical form. Number of infested and fresh fruits was recorded at each instance. Infestation (\%) was calculated as per the following:

$$
\text { Infestation (\%) }=\frac{\text { Infested fruits (No.) }}{\text { Total fruits observed (No.) }} \times 100
$$

Geographical location of the survey areas are presented in Table 1.

\section{Results and Discussion}

The observations pertaining with fruit fly infestation on guava at different districts under northern part of West Bengal have been presented in Table 2 . The data revealed that infestation by fruit fly on guava at different districts were significantly varied amongst various locations during 2014 and 2015. The fruit fly infestation (\%) on guava varied from 9.67-25.00\% and 8.67-28.33\% during 2014 and 2015, respectively.

However, two yearspooled mean values showed that the highest infested fruit (26.67\%) on number basis was observed at Posarir hat $\left(23^{\circ} 73^{\prime} \mathrm{N}, 88^{\circ} 23^{\prime} \mathrm{E}\right)$ locality and lowest $(10.50 \%)$ was noted at Matigara $\left(26^{\circ} 72^{\prime} \mathrm{N}, 88^{\circ} 38^{\prime} \mathrm{E}\right)$ and Kharibari $\left(26^{\circ} 55^{\prime} \mathrm{N}, 88^{\circ} 19^{\prime} \mathrm{E}\right)$ area.

\begin{tabular}{|c|c|c|c|}
\hline District & Location & Latitude & Longitude \\
\hline \multirow[t]{9}{*}{ Cooch Behar } & Chilkirhat & $26053 \mathrm{\prime} N$ & 89o 19'E \\
\hline & Morangabari & $21091 ' N$ & 87o 26'E \\
\hline & Posarir Hat & $23073^{\prime} \mathrm{N}$ & 88023 'E \\
\hline & Dinhata & $26013^{\prime} \mathrm{N}$ & 89046 'E \\
\hline & Vetaguri & $26020^{\prime} \mathrm{N}$ & $89048 ' E$ \\
\hline & Maruganj & $26030^{\prime} \mathrm{N}$ & 89056 'E \\
\hline & Pundibari & $26041^{\prime} \mathrm{N}$ & 890 38'E \\
\hline & Horir Hat & $26039^{\prime} \mathrm{N}$ & 89o 49'E \\
\hline & Sajerpar & $26029^{\prime} \mathrm{N}$ & 89o 19'E \\
\hline \multirow[t]{4}{*}{ Jalpaiguri } & Gadong-1 & $26055^{\prime} \mathrm{N}$ & 89o 10'E \\
\hline & Gadong-2 & $26054^{\prime} \mathrm{N}$ & 890 17'E \\
\hline & Moinaguri & $26057^{\prime} \mathrm{N}$ & 88082 'E \\
\hline & Dhupguri & $26058^{\prime} \mathrm{N}$ & 89o 00'E \\
\hline \multirow[t]{2}{*}{ Alipurduar } & Sonapur & $26046^{\prime} \mathrm{N}$ & 89o 39'E \\
\hline & Falakata & $26053^{\prime} \mathrm{N}$ & 89o 19'E \\
\hline \multirow[t]{5}{*}{ Darjeeling } & Chandmoni & $25026^{\prime} \mathrm{N}$ & 88002 'E \\
\hline & Naksalbari & $26070^{\prime} \mathrm{N}$ & 88042 'E \\
\hline & Matigara & $26072^{\prime} \mathrm{N}$ & $88038 ' E$ \\
\hline & Kharibari & $26055^{\prime} \mathrm{N}$ & 880 19'E \\
\hline & Phasidewa & $26058^{\prime} \mathrm{N}$ & 880 37'E \\
\hline
\end{tabular}

The information on fruit infestation by fruit flies from different localities under northern tract of West Bengal was subjected to cluster analysis and results have been presented in Table 3 and Table 4 . In table the statistics like mean, variance, minimum value, maximum value are mentioned and the places or location which are more or less approximately similar based on have been categorised in respective clusters. Significant differences have been detected among the clusters by performing Levens test of analysis.

During 2014, mean values of the data indicated that highest infestation was recorded as $21.28 \%$ in CL1 (Cluster 1 ) followed by $12.89 \%$ in CL2 (Cluster 2) presented in Table 3 . The highest fruit infestation was found to vary from $17.67-25.00 \%$ at different locations i.e. Naksalbari, Phasidewa, Maruganj, Posarir Hat, Vetaguri, Chilkirhat, Sonapur under northern part of West Bengal and the lowest infestation varied from 11.33$15.00 \%$ at Kharibari, Pundibari, Sajerpar, Falakata, Gadong 2, Matigara, Gadong 1, Chandmoni, Morangabari, Dhupguri, Moinaguri, Dinhata and Horir Hat in cluster 2 presented in Figure 1.

During 2015, mean values of the data revealed that the fruit fly inflicted highest infestation (22.52\%)on guava in CL1 (Cluster 1) followed by CL2 (Cluster 2) (12.15\%) presented 


\begin{tabular}{lccc}
\hline $\begin{array}{l}\text { Table 2: Fruit infestation (by number) by fruit flies on guava } \\
\text { during } 2014 \text { and } 2015 \text { in different parts of northern West } \\
\text { Bengal }\end{array}$ & & & \\
\hline Locations & 2014 & 2015 & $\begin{array}{c}\text { Pooled over } \\
(2014-2015)\end{array}$ \\
\hline Chilkirhat & $22.00(4.69)$ & $24.00(4.90)$ & $23.00(4.80)$ \\
Morangabari & $13.33(3.65)$ & $21.00(4.58)$ & $17.17(4.14)$ \\
Posarir Hat & $25.00(5.00)$ & $28.33(5.32)$ & $26.67(5.16)$ \\
Dinhata & $14.33(3.79)$ & $21.67(4.66)$ & $18.00(4.24)$ \\
Vetaguri & $21.00(4.58$ & $17.33(4.16)$ & $19.17(4.38)$ \\
Maruganj & $18.00(4.24)$ & $14.33(3.79)$ & $16.17(4.02)$ \\
Pundibari & $11.33(3.37)$ & $11.00(3.32)$ & $11.17(3.34)$ \\
Horir Hat & $15.00(3.87)$ & $12.67(3.56)$ & $13.83(3.72)$ \\
Sajerpar & $11.33(3.37)$ & $11.00(3.32)$ & $11.17(3.34)$ \\
Sonapur & $24.00(4.90)$ & $24.33(4.93)$ & $24.17(4.92)$ \\
Falakata & $12.00(3.46)$ & $19.67(4.44)$ & $15.83(3.98)$ \\
Gadong-1 & $12.67(3.56)$ & $24.00(4.90)$ & $18.33(4.28)$ \\
Gadong-2 & $12.00(3.46)$ & $12.00(3.46)$ & $12.00(3.46)$ \\
Moinaguri & $13.67(3.70)$ & $13.67(3.70)$ & $13.67(3.70)$ \\
Dhupguri & $13.67(3.70)$ & $22.33(4.73)$ & $18.00(4.24)$ \\
Chandmoni & $13.00(3.61)$ & $12.33(3.51)$ & $12.67(3.56)$ \\
Naksalbari & $17.67(4.20)$ & $11.00(3.32)$ & $14.33(3.79)$ \\
Matigara & $12.33(3.51)$ & $8.67(2.94)$ & $10.50(3.24)$ \\
Kharibari & $9.67(3.11)$ & $11.33(3.37)$ & $10.50(3.24)$ \\
Phasidewa & $17.67(4.20)$ & $17.00(4.12)$ & $17.33(4.16)$ \\
\hline Figures withi & parenthesis are square root transormed
\end{tabular}

${ }^{*}$ Figures within parenthesis are square root transormed values.

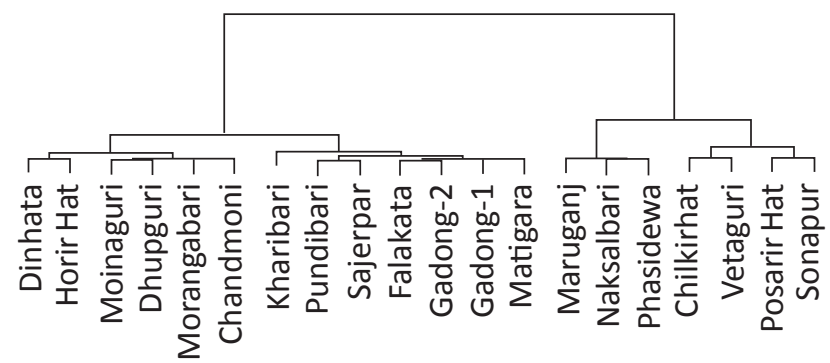

Figure 1: Cluster dendogramon intensity of fruit fly infestation on guava at different locations during 2014

in Table 4. The highest infestation was varied from 17.33 to 28.33\% at Phasidewa, Vetaguri, Falakata, Moranga, Dinhata, Dhupguri, Chilkirhat, Gadong1, Sonapur, Posarir Hat and the lowest infestation was varied from 11.00 to $14.33 \%$ at Matigara, Naksalbari, Pundibari, Sajerpar, Kharibari, Gadong2, Chandmoni, Horir Hat, Moinaguri and Maruganj presented in Figure 2.

Similar results were earlier reported by Hasseb (2007) who found $20-46 \%$ fruit fly infestation on guava. Highest crop
Table 3: Cluster analysis of fruit fly infestation on guava in different locations during 2014

\begin{tabular}{|c|c|c|c|c|c|}
\hline \multirow{2}{*}{$\begin{array}{l}\text { Clus- } \\
\text { ter } \\
\text { no. }\end{array}$} & \multicolumn{4}{|c|}{ Fruit infestation (\%) } & \multirow[t]{2}{*}{ Name of the locations } \\
\hline & Mean & $\begin{array}{l}\text { Vari- } \\
\text { ance }\end{array}$ & $\begin{array}{l}\text { Min. } \\
\text { value }\end{array}$ & $\begin{array}{l}\text { Max. } \\
\text { value }\end{array}$ & \\
\hline CL1 & 21.28 & 9.470 & 17.67 & 25.00 & $\begin{array}{l}\text { Naksalbari, Phaside- } \\
\text { wa, Maruganj, Po- } \\
\text { sarir Hat, Vetaguri, } \\
\text { Chilkirhat, Sonapur }\end{array}$ \\
\hline CL2 & 12.89 & 2.027 & 11.33 & 15.00 & $\begin{array}{l}\text { Kharibari, Pundibari, } \\
\text { Sajerpar, Falakata, } \\
\text { Gadong2, Matigara, } \\
\text { Gadong1, Chand } \\
\text { moni, Morangabari, } \\
\text { Dhupguri, Moinaguri, } \\
\text { Dinhata, Horir Hat }\end{array}$ \\
\hline \multicolumn{3}{|c|}{ Levens test Statistic } & & 14.32 & \\
\hline \multicolumn{3}{|c|}{$p$-value } & & 0.001 & \\
\hline
\end{tabular}

\section{$\mathrm{CL}$ : Cluster}

Table 4: Cluster analysis of fruit fly infestation on guava in different locations during 2015

\begin{tabular}{|c|c|c|c|c|c|}
\hline \multirow{2}{*}{$\begin{array}{l}\text { Clus- } \\
\text { ter } \\
\text { no. }\end{array}$} & \multicolumn{4}{|c|}{ Fruit infestation (\%) } & \multirow{2}{*}{$\begin{array}{l}\text { Name of the loca- } \\
\text { tions }\end{array}$} \\
\hline & Mean & $\begin{array}{l}\text { Vari- } \\
\text { ance }\end{array}$ & $\begin{array}{l}\text { Min. } \\
\text { value }\end{array}$ & $\begin{array}{l}\text { Max. } \\
\text { value }\end{array}$ & \\
\hline CL1 & 22.52 & 11.887 & 17.33 & 28.33 & $\begin{array}{l}\text { Phasidewa, Vetaguri, } \\
\text { Falakata, Morang- } \\
\text { aba, Dinhata, Dh- } \\
\text { upguri, Chilkirhat, } \\
\text { Gadong1, Sonapur, } \\
\text { Posarir Hat }\end{array}$ \\
\hline CL2 & 12.15 & 2.548 & 11.00 & 14.33 & $\begin{array}{l}\text { Matigara, Naksal- } \\
\text { bari, Pundibari, Sa- } \\
\text { jerpar, Kharibari, Ga- } \\
\text { dong2, Chandmoni, } \\
\text { Horir Hat, Moina- } \\
\text { guri, Maruganj }\end{array}$ \\
\hline \multicolumn{3}{|c|}{ Levens test Statistic } & & 4.85 & \\
\hline \multicolumn{3}{|c|}{$p$-value } & & 0.04 & \\
\hline
\end{tabular}

$\mathrm{CL}$ : Cluster

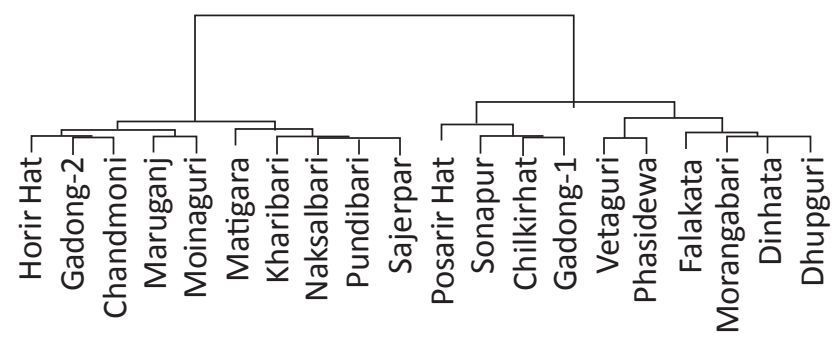

Figure 2: Cluster dendogramon intensity of fruit fly infestation on guava at different locations during 2015 
loss of about $80 \%$ in guava was reported by Kafi (1986) and Ishtiaque et al. (1999) in Pakistan. Similarly Jalaluddin et al. (1999) reported $60-80 \%$ loss in guava fruit by Bactrocera correcta (Bezzii) while Verghese et al. (2002b) reported infestation by fruits flies to guava ranged from 5-7\%. In previous studies, Mehmood and Mishkatullah (2007) who found the highest fruit fly infestation (80\%) in guava orchards in ripening stage.

Yan-mei et al. (2011) also reported that the fruit damage rate of guava was $6.67-7.33 \%$ by oriental fruit fly. Fruit loss in guava orchards infested due to fruit fly was estimated to the extent of 13.40 to $46.60 \%$ and $12.50-42.86 \%$, respectively on weight basis and number basis was reported by Ukey et al. (2012). Kakar et al. (2014) also reported that the fruit fly infestation was varied from 3.00-49.67\% on guava in Khyber Pakhtunkhawa. Thus, results of the present study are in corroboration with the previous findings.

\section{Conclusion}

The fruit fly infestation fluctuate considerably in different locations of Terai region of West Bengal. Maximum fruit fly infestation (26.67\%) was observed in Posarir Hat whereas minimum (10.50\%) in Matigara and Kharibari regions. These observations can be considered as a critical window for the management of fruit flies on gauva in West Bengal.

\section{References}

Hasseb, M., 2007. Current status of insect pest problems in guava. Acta Horticulture 735, 453-467.

Ishtiaque, A.F., Ullah, A.U.R., Alam, S., 1999. Efficacy of various insecticides and trap height in Methyl Eugenol baited traps against fruit flies (Bactrocera spp.). Sarhad Journal of Agriculture 15, 589-594.

Jalaluddin, S.M., Natarajan, K., Kathulla, S.S., Balasubramaniyan, S., 1999. Discovery of the guava fruit fly, Bactrocera correcta (Bezzi). Entomon 24(2), 195-196.

Kafi, A., 1986. Progress and problems in controlling fruit flies infestation. Paper presented at FAO, RAPA, Bangkok, Thailand, 16-19.

Kakar, M.Q.F., Ullah, A.U.R., Saljoqi, S., Ali, I., 2014. Determination of fruit flies (Diptera: Tephritidae) infestation in guava, peach and bitter gourd orchards in Khyber Pakhtunkhwa during 2010 and 2011. Sarhad Journal of Agriculture 30(2), 241-246.

Mehmood, K., Mishkatullah., 2007. Population dynamics of three species of genus Bactrocera (Diptera; Tephritidae; Dacinae) in BARI Chakwal (Punjab). Pakistan Journal of Zoology 39(2), 123-127.

NHM., 2012. IPM Schedule for guava pests. National Horticulture Mission, Ministry of Agriculture Department of Agriculture and Cooperation Krishi Bhawan, New Delhi.

Sikhamany, S.D., Murti, G.S.R., 2005. Shift in Policies. In: Ram, N., (Eds.). Hindu Survey of Indian Agriculture, National Press, Kasturi Building, Chennai, 143-146.

Stonehouse, J.M., Verghese, A., Mumford, J.D., Thomas, J., Jiji, T., Faleiro, R., Patel, Z.P., Jhala, R.C., Patel, R.K., Shukla, R.P., Satpathy, S., Singh, H.S., Singh, A., Sardana, H.R., 2005. Research conclusions and recommendations for the on-farm IPM of Tephritid fruit flies in India. Pest Management in Horticultural Ecosystem 11, 172-218.

Ukey, N.S., Galande, S.M., Wagh, S.S., 2012. Studies on losses of guava fruits by fruit fly, Bactrocera spp. In Pune region of Maharastra state. International Journal of Plant Protection 5(1), 181-182.

Verghese, A., Madhura, H.S., Kamala Jayanthi, P.D., Stonehouse, J.M., 2002a. Fruit flies of economic significance in India, with special reference to Bactrocera dorsalis (Hendel). Proceedings of $6^{\text {th }}$ International Fruit fly Symposium, Stellenbosch, South Africa. 6-10 May 2002, 317-324.

Verghese, A., Nagaraju, A., Sreedevi, N.N., 2002b. Pre and post harvest IPM for management of mango fruit fly, Bactrocera dorsalis (Hendel). Proceedings of seventh International Symposium on Fruit Flies of Economic Importance, Salvador, Brazil. 10-12 September 2006. 179-182.

Yan-mei, L., Dong-qing, Shu-Chang, H., Li-yuan, X., 2011. Study on integrated control against oriental fruit fly, Bactrocera dorsalis (Hendel) in guava orchard. Plant Diseases and Pests 2(2), 47-50. 